\title{
Methodology for Managing Sustainable Socio-Ecological and Economic Development in an Innovation Focused Economy
}

\author{
Kudryashova T.V. \\ Yaroslav the Wise Novgorod State University, \\ Veliky Novgorod, Russia, \\ tatyana.kudryashova@novsu.ru
}

\author{
Malyshev A.A. \\ Penza State Technological University, \\ Penza, Russia, \\ malyshe-aleksej@yandex.ru
}

\author{
Korobkova N.A. \\ Penza State University of Architecture and Construction, \\ Penza, Russia, \\ korobkova-natalia@mail.ru
}

\begin{abstract}
The article discusses the understanding of sustainable development in the economy. It characterizes the main approaches to the substitution of natural resources by human capital. The problems of sustainable development, solved by modern science, are presented. The authors reveal the content of approaches to understanding sustainable development from the point of view of ecologists and economists and discuss the ideas of rejecting economic growth and limited growth. The absence of correlation between economic growth and the wellbeing of the population is underlined. The article formulates conditions for achieving sustainable development in an innovation focused economy. The important role of the state in the development and implementation of innovations for the purposes of ensuring sustainable development is substantiated. The authors prove the necessity of structural transformations of the economy for solving the problems of sustainable development. Structural transformations will be aimed at maintaining the employment of the population in the context of the introduction of innovations, the change of approaches to rent management is planned to form the social orientation of the economy. A mechanism for regulating economic sectors is considered necessary for the development of industries that contribute to improving the population welfare. The research allowed defining the main state functions in terms of sustainable development and helped substantiate the need to focus on limited economic growth. The article was prepared within the framework of the scientific project No. 20-010-00875A "Problems of managing sustainable socio-ecological and economic development of Russia and ways to solve them" with the support of the Russian Foundation for Basic Research.
\end{abstract}

Keywords—sustainable development, innovative economy, limited economic growth

\section{INTRODUCTION}

It is obvious that economic management should focus on sustainable development. This problem was discussed by the UN member states in 2015. The summit was held to adopt the "Agenda for Sustainable Development until 2030", which included the definition of Sustainable Development Goals for all countries. The new goals imply the introduction of a development model, in which an increase in the well-being of the population and economic growth will be ensured without environmental degradation [1].

Serious restrictions imposed in connection with the spread of the corona virus infection COVID-19 have slowed down economic development and led to a serious recession in most countries. According to the World Bank, the world economy will contract by more than $5 \%$, which is the worst crisis in the last 70 years [2]. Developed countries are expected to be hit hard, with economic activity shrinking by $7 \%$. For developing economies, a decline of $2.5-2.7 \%$ is predicted. However, in some countries the drop in GDP will be more significant. According to IHSMarket, the fall in India will amount to $11 \%$ of GDP [3].

On the other hand, numerous researchers have noted a positive impact on the ecological situation as a consequence of the introduced restrictions [4]. Social distancing and shutdown of a number of enterprises led to a reduction in emissions of pollutants and a drop in their level to the values of the 1960s. [5]. It was caused by both the termination of the work of enterprises and a decrease in traffic flows. Environmentalists note a reduction in waste and an improvement in the quality of water on the beaches due to a serious reduction in tourist flows. 
At first glance, these trends indicate a balance in terms of sustainable development: losses in the economic sphere are compensated by advantages in the environmental sphere. There is no doubt that there is a correlation between economic growth and environmental degradation, and vice versa. However, correlation assessment is not possible because of the complexity of the systems under study. Therefore, a different understanding of the sustainable development management process is required

\section{RESULTS AND DISCUSSION}

Economic science understands sustainable development as the non-decreasing welfare of the population or consumption per capita over time [6,7]. At the same time, an increase in wellbeing and a non-decreasing stock of capital transferred to the next generation is desirable [8]. The capital stock is the total cost of the main factors of production, including human resources.

Natural capital is the most difficult in terms of preservation and transfer to future generations. In addition to the stock of natural resources, it includes ecosystem services [9]: climate stabilization, regulation of precipitation, water purification, etc. Researchers believe that natural capital can decline as long as this process is compensated by an increase in the efficiency of other resources usage, including an increase in the total cost of production means, advanced training of employees, etc.

Thus, the concept of sustainable development presupposes the interchangeability of various types of capital. There is also another view of sustainable development concept: it assumes that sustainable development cannot be achieved by investing the rent of non-renewable natural resources in renewable ones. Accordingly, it is necessary to reduce the natural resources consumption. The fundamental difference between these approaches is the assumption of the interchangeability of resources and the possibility of replacing natural capital with artificially created one.

Systematizing these approaches to sustainability, R.K. Turner identified 4 types of sustainability [10]: 1) very weak; 2) weak; 3) strong; 4) very strong.

The weakest sustainability was first described by J. Hartwick; it means unlimited replacement of natural resources by human capital [11]. Representatives of the thermodynamic school adhere to the positions of strong sustainability; they insist that the replacement of natural capital whether by artificial capital or by natural capital of another kind is unacceptable [12].

Most researchers believe that there is a certain critical mass, up to which it is possible to replace natural capital with another capital (weak sustainability) or another natural resource (strong sustainability) [13].

At the present stage of science development the concept of sustainable development is undergoing changes due to the growing interest in these research areas. The central research questions are as follows: What long-term tendencies appear in changing the environment and in the development of interaction between nature and society? What factors determine the limits of resilience and sources of dynamic systems vulnerability [14]? What tools and methods will increase the effectiveness of socioeconomic systems management? What scientific achievements will ensure the sustainability of the socio-ecological and economic system [15]?
That is, sustainable development as an approach to management is changing the guidelines and priorities. From the basic concept of development, it becomes the basis for the development of practical problems of life support for the Earth population. In recent years, special attention has been paid to mitigating the pressure on the global climate, preserving the ecosystem of services and protecting biodiversity, etc. Accordingly, scholars seeking to advance the transition to sustainability organize cutting-edge research in areas ranging from complex systems theory to cultural and political ecology. As a result, more and more often the solution to the problems of sustainable development is viewed from the perspective of applied research.

We believe that the solution to sustainable development problem should be sought not in applied research, but in methodology. Since the 1960s, when the first ecological movements arose, and up to the present, the search for the optimum in the interaction of ecology and economics continues. In the course of this search, radical theories of abandoning economic growth [16] and the idea of significant regulatory restrictions on economic growth appeared [17]. The issues of eco-socialism [18] were studied, they speak about building an economic development model in which the environment is not damaged and all people are equal in terms of well-being. The problems of ecology and limited economic growth are considered by feminist philosophical science [19]. However, the considered areas of research are not in the mainstream of ecological economics.

Economic growth is still more important than environmental protection, but a reasonable question arises if economic growth is an indicator of the population well-being. Economic growth implies an increase in the volume of goods and services production in the economic system. However, an increase in domestic production does not mean an increase in the consumption of goods and services. For example, in 2009 in Russia there was a $7.8 \%$ drop in the GDP indicator compared to the previous year [20], and the disposable income of the population for the same period increased by $3 \%$ [21]. Partially, this trend was caused by an increase in government spending during the crisis period. But the crisis manifested itself with renewed vigor in 2014-2015, and in the same period, there was a decrease in disposable income of the population by 1-3\%. Consequently, economic growth indirectly indicates the dynamics of population well-being.

The conclusion that economic growth calculated through the calculation of GDP does not show the actual situation in the economy was confirmed by the world leading economists. Commission for Measuring Economic Efficiency and Social Progress organized with the participation of Joseph Stiglitz and Amartya Sen, Nobel laureates in economics, has proved that the subordination of economic policy to GDP growth does not lead a society to prosperity and threatens negative consequences for its future [22]. However, while solving this problem, many researchers seek to improve the calculation of economic growth indicators or offer an alternative [23], which is not always justified.

It has been proven many times that the growth of economic activity measured by GDP leads to an increase in greenhouse gas emissions and a greater use of resources [24, 25]. It can be assumed that achieving the necessary reductions in greenhouse gas emissions and resource use is likely to lead to a decrease in 
GDP growth. Therefore, without radical economic transformations, such a decline in GDP growth will have disastrous social consequences. We believe that the introduction of innovative technologies will foster solution of the above problems. However, the development of innovations and the introduction of new technologies should be carried out regarding their environmental rather than economic component.

Innovation is a risky and expensive investment. Therefore, during the implementation of an innovative product, the costs and risks should pay off. The choice of implemented innovations is based on the potential income that they should bring. This approach seems to be wrong from the point of view of sustainable development; innovations should help to reduce the negative impact on the environment. Private capital rarely makes such decisions, since they are not economically viable. Therefore, the leading role in the development and implementation of such innovations should be given to the state.

It seems that the time has come for changing the paradigm of sustainable development management. Sustainable development, which gives priority to the accumulation of capital, should give way to social and environmental development in the limited growth conditions. It requires institutional transformation of the whole society.

One of the change directions is the "private rent" institution. Private property is one of the pillars of the market economy, and it must remain constant. But, in regards to property, primarily land ownership and a number of other assets, existing institutions should be reorganized. In recent decades, there have been shifts in investment models: a decrease in productive investment, where profitability is ensured by the innovation introduction and production growth; an increase in non-productive investment, where income is obtained through the economic rent extraction. Basically, such investments are investments in existing assets: land, financial assets [26], or assets associated with making "access restrictions" [27]. According to the theory of rent by J. Locke, the owners of assets receive surplus profits by controlling those assets that cannot be quickly and widely reproduced. In the context of limiting the use of resources and reducing emissions, which will mitigate the environmental collapse, prices for such assets will increase, and, accordingly, surplus profits will increase. Environmental economists should consider who will be able to receive this rent and who will bear its burden $[28,29,30]$.

It seems expedient to redirect part of the received "superrent" to finance research in the field of resource-efficient innovations.

The state will also have to deal with the corresponding redistribution.

A significant challenge for sustainable innovation development is the changing demand for labor. A stable income is a fundamental factor in ensuring the well-being of the population. However, the growing demand for innovative products and cost-effective technologies can crowd out workers due to automation or redistribution of production. Therefore, in the context of innovations introduction, the question remains whether the increase in spending on domestic consumption of goods and services compensates for the negative impact of technological changes on employment. A number of authors adhere to a position that it does compensate [31]; others argue that compensation is possible when innovative products are introduced, but the introduction of innovative technologies makes it difficult [32]. We agree with the views of the latter, but we underline that ensuring innovation-oriented sustainable growth is possible with the introduction of technologies, not products introduction. Innovative products stimulate the growth of demand, and, accordingly, an increase in production. A "vicious circle" appears: either we get an increase in production volumes and, accordingly, an increase in resource consumption, or a situation arises when resource consumption decreases with the introduction of new technologies, but the labor force is released. Any of the considered options leads to destabilization of sustainable development. It means that the introduction of innovative technologies should be accompanied with changes in the sector structure of production, taking into account the formation of laborintensive industries.

In the research literature, there is no general point of view on the desired structural changes and ways to achieve them. Researchers identify a number of areas that need to be reduced, for example, speculative financing [33], and resource extraction [34]. From the sustainable development point of view, sectors with high employment of the population remain desirable, especially labor-intensive services [35].

Many studies propose to carry out structural changes in the economy depending on the efficiency of energy consumption [36]. High energy consumption implies consumption of more resources and has great consequences for the environment. The abandonment of production in this area will positively affect the achievement of sustainable growth goals. Other researchers go even further and estimate the energy consumption during the production and its quantity in the manufactured product (typical for agricultural products). For example, F. Seculova et al [37] prove the high fuel dependence of the Spanish agricultural sector, where the energy consumption for the production process is six times higher than the energy contained in ready food products. The authors conclude that it is necessary to abandon the cultivation of certain crops. It seems that the discussion on the definition of industries requiring structural changes is one of the key issues in the sustainable development management [38].

\section{CONCLUSION}

The specified problems and contradictions of sustainable development require a revision of the methodology for managing socio-ecological and economic development in an innovative economy. The emerging approach to management requires an increase in the role of the state. The existing instruments do not solve the problem of sustainable development. Eliminating negative externalities by regulating taxation becomes irrelevant when considering transaction costs. At the same time, new functions of the state should appear: changing the institution of "private rent", selecting and introducing environmentally friendly innovative technologies, creating prerequisites for changing the structure of the economy in order to redistribute the share from energyintensive to labor-intensive sectors. 


\section{References}

[1] UN, section "Sustainable Development Goals", Retrieved from https://sdgs.un.org/

[2] World Bank, Retrieved from https://www.worldbank.org/en/news/pressrelease/2020/06/08/covid-19-to-plunge-global-economy-into-worstrecession-since-world-war-ii

[3] IHSMarket, $\quad$ Retrieved from https://news.ihsmarkit.com/INFO/covid19/3474

[4] M.A. Zambrano-Monserrate, M.A. Ruano and L. Sanchez-Alcalde, "Indirect effects of COVID-19 on the environment", Science of The Total Environment, 2020, vol. 728, DOI https://doi.org/10.1016/j.scitotenv.2020.138813

[5] Carbon Monitor, Retrieved from https://carbonmonitor.org/

[6] K.J. Arrow, P. Dasgupta, L.H. Goulder, K.J. Mumford and K. Oleson, "Sustainability and the measurement of wealth", Environment and Development Economics, 2012, vol. 17(3), pp. 317-353.

[7] L. Oxley, N. Hanley, D. Greasley, E. McLaughlin and M. Blum, "Empirical testing of genuine savings as an indicator of weak sustainability: a three country analysis of long run trends", Environmental and Resource Economics, 2016, vol. 63(2), pp. 313-338.

[8] S.N. Silvestrov and B.N. Porfirjev, "National wealth: assessment and management of economic development" ["Natsional'noye bogatstvo: otsenka i upravleniye ekonomicheskim razvitiyem"], in S.M. Shakhrai, E.I. Ivanova (Eds.), NII SP.-M.: Ekonomicheskie nauki, 2008. (In Russ.).

[9] I.J. Bateman and R.K. Turner, "Valuation of the environment, methods and techniques: The contingent valuation method", in R.K. Turner (ed.), "Sustainable Environmental Economics and Management: Principles and Practice", Belhaven Press, London, 1993, pp. 120-191.

[10] J.M. Hartwick, "Intergenerational Equity and the Investing of Rents from Exhaustible Resources", The American Economic Review, 1977, vol. 67(5), pp. 972-974.

[11] I.B. Sergeyev and L.V. Lapochkina, "Sustainable Development: Theoretical and Methodological Approaches" ["Ustoychivoye razvitiye: teoretiko-metodologicheskiye podkhody"], Notes of the Mining Institute [Zapiski Gornogo instituta], 2009, vol. 184, pp. 244-269. (In Russ.). Retrieved from https://cyberleninka.ru/article/n/ustoychivoe-razvitieteoretiko-metodologicheskie-podhody

[12] D. Pearce and G. Atkinson, "Capital theory and the measurement of sustainable development: An indicator of «weak» sustainability", Ecological Economics, 1993, vol. 8(2), pp. 103-108.

[13] P. Weißhuhn, F. Müller and H. Wiggering, "Ecosystem Vulnerability Review: Proposal of an Interdisciplinary Ecosystem Assessment Approach", Environmental Management, 2018, vol. 61, pp. 904-915. DOI: https://doi.org/10.1007/s00267-018-1023-8

[14] C.W. Clark, "Sustainability Science: A room of its own", in Proceedings of the National Academy of Sciences, 2007, vol. 104(6), pp. 1737-1738. DOI: https://doi.org/10.1073/pnas.0611291104

[15] H.E. Daly, "In defense of a steady-state economy", American Journal of Agricultural Economics, 1972, vol. 54(5), pp. 945-954. DOI: https://doi.org/10.2307/1239248

[16] J. Martinez-Alier, U. Pascual, F.D. Vivien and E. Zaccai, "Sustainable de-growth: Mapping the context, criticisms and future prospects of an emergent paradigm". Ecological Economics, 2010, vol. 69(9), pp. 17411747.

[17] A. Douai, "Ecological Marxism and Ecological Economics: From Misunderstanding to Meaningful Dialogue", in C.L. Spash (Ed.), "Routledge Handbook of Ecological Economics: Nature and Society", Abingdon: Routledge, 2017, pp. 57-66.

[18] P.E. Perkins, "Women, ecology and economics: New models and theories", Ecological Economics, 1997, vol. 20(2), pp. 105-106. DOI: https://doi.org/10.1016/s0921-8009(96)00459-4

[19] J.A. Nelson, "Economists, value judgments, and climate change: A view from feminist economic", Ecological Economics, 2008, vol. 65(3), pp. 441-447. DOI: https://doi.org/10.1016/j.ecolecon.2008.01.001
[20] Federal State Statistics Service of the Russian Federation, Retrieved from https://rosstat.gov.ru/accounts

[21] Federal State Statistics Service of the Russian Federation, Retrieved from https://rosstat.gov.ru/folder/13397

[22] J. Stiglitz, A. Sen and J. Fitoussi, "Mismeasuring our Lives: Why GDP Doesn't Add Up", The New Press, New York, 2010.

[23] I. Kubiszewski, R. Costanza, C. Franco, Ph. Lawn, J. Talberth, T. Jackson and C. Aylmer, "Beyond GDP: Measuring and achieving global genuine progress", Ecological Economics, 2013, vol. 93, pp. 5768. DOI: https://doi.org/10.1016/j.ecolecon.2013.04.019

[24] Z. Csereklyei, M.M. Rubio-Varas and D.I. Stern, "Energy and economic growth: The stylized facts", Energy Journal, 2016, vol. 37(2), pp. 223255. DOI: https://doi.org/10.5547/01956574.37.2.zcse

[25] T.O. Wiedmann, H. Schandl, M. Lenzen, D. Moran, S. Suh, J. West and K. Kanemoto, "The material footprint of nations", in Proceedings of the National Academy of Sciences of the United States of America, 2015, vol. 112(20), pp. 6271-6276. https://doi.org/10.1073/pnas.1220362110

[26] B. Stratford, "The Threat of Rent Extraction in a Resource-constrained Future", Ecological Economics, 2020, vol. 169, p. 106524, DOI: https://doi.org/10.1016/j.ecolecon.2019.106524

[27] D. Andreucci, M. García-Lamarca, J. Wedekind and E. Swyngedouw, "«Value grabbing»: a political ecology of rent capital". Capitalism, Nature, Socialism, 2017, vol. 28(3), p. 28-47. DOI: https://doi.org/10.1080/10455752.2016.1278027

[28] J.K. Boyce, "Carbon pricing: effectiveness and equity". Ecological Economics, 2018, vol. 150, pp. 52-61. DOI: https://doi.org/10.1016/j.ecolecon.2018.03.030

[29] R. Felli, "On climate rent", Historical Materialism, 2014, vol. 22(3-4), pp. 251-280. DOI: https://doi.org/10.1163/1569206X-12341368

[30] U. Kornek, J.C. Steckel, K. Lessmann and O. Edenhofer, "The climate rent curse: new challenges for burden sharing", Int Environ Agreements, 2017, vol. 17, pp. 855-882. DOI: https://doi.org/10.1007/s10784-0179352-2

[31] D.J. Bertulfo, E. Gentile and G. Vries, "The Employment Effects of Technological Innovation, Consumption, and Participation in Global Value Chains: Evidence from Developing Asia", Asian Development Bank Economics Working Paper Series, 2019, vol. 572. DOI: https://dx.doi.org/10.2139/ssrn.3343998

[32] J. Ortiz and V.S. Fumás, "Technological innovation and the demand for labor by firms in expansion and recession", Economics of Innovation and New Technology, 2020, vol. 29(4), pp. 417-440. DOI: https://doi.org/10.1080/10438599.2019.1629535

[33] H.E. Daly, "A steady-state economy", Opin. Piece Redefining Prosper Sustainable Development Commission, UK, 2008, pp. 1-10.

[34] F. Sekulova, G. Kallis, B. Rodríguez-Labajos and F. Schneider, "Degrowth: from theory to practice", Journal of Cleaner Production, 2013, vol. $38, \quad$ pp. $\quad 1-6 . \quad$ DOI https://doi.org/10.1016/j.jclepro.2012.06.022

[35] T. Jackson, "The Post-growth Challenge: Secular Stagnation, Inequality and the Limits to Growth", Ecological Economics, 2019, vol. 156, pp. 236-246. DOI: https://doi.org/10.1016/j.ecolecon.2018.10.010

[36] L. Hardt, J. Barrett, P.G. Taylor and T.J. Foxon, "Structural change for a post-growth economy: investigating the relationship between embodied energy intensity and labour productivity", Sustainability, 2020, vol. 12(962), pp. 1-25. DOI: https://doi.org/10.3390/su12030962

[37] F. Sekulova, G. Kallis, B. Rodríguez-Labajos and F. Schneider, "Degrowth: from theory to practice", Journal of Cleaner Production, 2013, vol. 38, pp. $\quad 1-6 . \quad$ DOI https://doi.org/10.1016/j.jclepro.2012.06.022

[38] A.A. Malyshev and N.N. Solodkov, "Models of international integration and factors of sustainable economic growth" ["Modeli mezhdunarodnoy integratsii i faktory ustoychivogo ekonomicheskogo rosta"], Cornfield of Povolzhje [Niva Povolzhja], 2014, vol. 4(33). pp. 144-150. (In Russ.). 